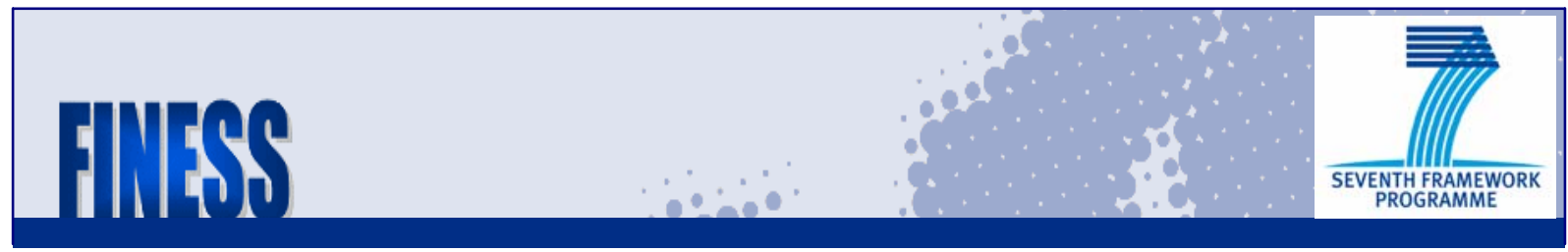

Project funded under the Socio-economic Sciences and Humanities

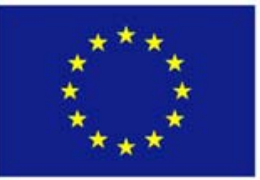

Working Paper D.3.1B

European Commission

\title{
Bad Bank(s) and Recapitalization of the Banking Sector
}

\author{
Dorothea Schäfer \\ DIW Berlin and Free University of Berlin, \\ Klaus F. Zimmermann \\ DIW Berlin, IZA, CEPR, University of Bonn
}

Berlin

May 30, 2009 


\title{
Bad Bank(s) and Recapitalization of the Banking Sector
}

\author{
Dorothea Schäfer und Klaus F. Zimmermann
}

\begin{abstract}
With banking sectors worldwide still suffering from the effects of the financial crisis, public discussion of plans to place toxic assets in one or more bad banks has gained steam in recent weeks. The following paper presents a plan how governments can efficiently relieve ailing banks from toxic assets by transferring these assets into a work publicly sponsored work out units, a so-called bad bank. The key element of the plan is the valuation of troubled assets at their current market value - assets with no market would thus be valued at zero. The current shareholders will cover the losses arising from the depreciation reserve in the amount of the difference of the toxic assets' current book value and their market value. Under the plan, the government would bear responsibility for the management and future resale of toxic assets at its own cost and recapitalize the good bank by taking an equity stake in it. In extreme cases, this would mean a takeover of the bank by the government. The risk to taxpayers from this investment would be acceptable, however, once the banks are freed from toxic assets. A clear emphasis that the government stake is temporary would also be necessary. The government would cover the bad bank's losses, while profits would be distributed to the distressed bank's current shareholders. The plan is viable independent of whether the government decides to have one centralized bad bank or to establish a separate bad bank for each systemically relevant banking institute.

Under the terms of the plan, bad banks and nationalization are not alternatives but rather two sides of the same coin. This plan effectively addresses three key challenges. It provides for the transparent removal of toxic assets and gives the banks a fresh start. At the same time, it offers the chance to keep the cost to taxpayers low. In addition, the risk of moral hazard is curtailed. The comparison of the proposed design with the bad bank plan of the German government reveals some shortcomings of the latter plan that may threaten the achievement of these key issues.
\end{abstract}

JEL Classification: G20, G24, G28

Keywords: Financial crisis, Financial Regulation, Toxic Assets, Bad Bank 


\section{Table of Contents}

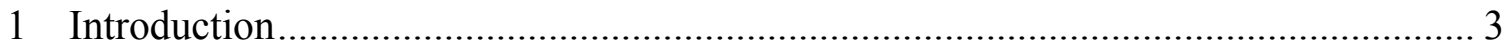

2 Weak Capital Basis of German Banks.................................................................. 5

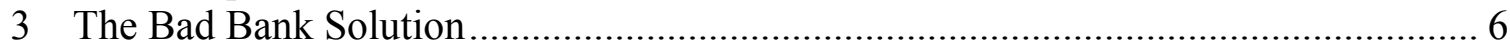

3.1 Historical Examples of Bad Banks ................................................................... 7

3.2 Prerequisites for the Success of a Bad Bank ...................................................... 9

4 Methods of Capitalization and Organizational Structure ........................................ 11

4.1 Classification of Historical Precedents and Proposed Models ........................... 12

4.2 Successful historical examples ............................................................................ 13

4.3 Proposed Models for the Current Crisis.............................................................. 13

5 Efficient Design for a Public Bad Bank.................................................................... 14

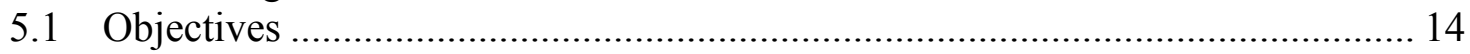

5.2 Key Elements of the Bad Bank Design............................................................. 14

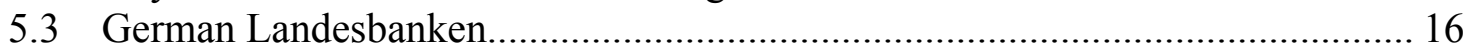

6 The Bad Bank Plan of the German Government ......................................................... 17

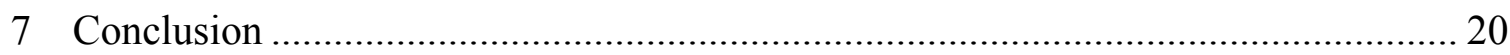

Appendix 1: Example of how the proposed bad bank design works ............................... 24

Appendix 2: Example of how the German government's bad bank plan works ............. 26

\section{Introduction}

Public discussion concerning the structural dislocation of the global financial system continues unabated. With the escalation of the financial crisis in the fall of 2008, many economists advocated internationally coordinated steps to recapitalize the banking sector. The recapitalization of distressed banks via public funds as well as the creation of bad banks for toxic assets were both proposed early on, yet the international community continues to debate potential solutions. ${ }^{a}$ While a general consensus on the principles for the reorganization of global financial markets was reached at the G-20 conference in Washington D.C. on November 15, 2008, the implementation of concrete measures was not addressed until the G-20 conference in London on April 2, 2009.

\footnotetext{
a cf. Zimmermann, K. F. 2008: "Coordinating International Responses to the Crisis", in Eichengreen, B., B. Richard (eds.), Rescuing Our Jobs and Savings: What G7/8 Leaders Can Do to Solve the Global Credit Crisis. The booklet is published on http://www.voxeu.org/index.php?q=node/2340 and is documented in German in Schäfer, D. (Ed.): Finanzmärkte im Umbruch: Krise und Neugestaltung, Vierteljahrshefte zur Wirtschaftsforschung 1-2009, DIW Berlin, pp. 167-209. Zimmermann, K. F. et al.: Europas Bankenkrise: Ein Aufruf zum Handeln. Führende Ökonomen rufen Europa zu schnellem Vorgehen in der Finanzmarktkrise auf. Documented in the same issue, pp. 210-212. Sachverständigenrat: Jahresgutachten 2008/09: Die Finanzkrise meistern - Wachstumskräfte stärken, www.sachverstaendigenrat-wirtschaft.de.
} 
Efforts to master the crisis have fallen short so far. Measures have been primarily implemented at a national level, if they have been implemented at all. As in many other countries, the bank rescue package in Germany has only been partially successful. The package's provisions for the sale of toxic assets have hardly been taken advantage of to date. The debate in Germany concerning the structural reforms necessary as a result of the crisis has drawn renewed attention to existing weaknesses such as the question of whether Germany needs another internationally competitive mega-bank or the still unresolved issue of the economic purpose of the 7 federal state banks (Landesbanken). These public banks are partly owned by either one or several German federal states and partly by savings banks. Several Landesbanken have invested large amounts of money into structured products that became toxic in the course of the financial crisis.

Against this backdrop, it seems advisable to maintain a clear separation between the plans for the removal of toxic assets and the plans to address other structural issues. The creation of bad banks is becoming ever more necessary. The government must confront the problems at hand with a proactive industrial policy so that it can retreat from interventionist measures as quickly as possible. At the same time, the necessary structural adjustments must soon be implemented at private and public banks; German banks must quickly regain their function as sources of credit and as institutes which serve the real economy, in order to counteract the cyclical downturn.

In this paper, we analyse how a bad bank plan can be efficiently designed and evaluate existing proposals, in particular the bad bank plan of the German government. In order to be efficient, a bad bank plan has to address three key challenges. It has to provide for the transparent removal of toxic assets and give the remaining good banks a fresh start. At the same time, the cost to taxpayers has to be kept to a minimum. Finally, the risk of future moral hazard has to be curtailed. The key element of the plan is the valuation of troubled assets at their current market value - assets with no market would thus be valued at zero. The current shareholders will cover the resulting losses. Under the plan, the government would bear responsibility for the management and future resale of toxic assets at its own expense and recapitalize the good bank by taking an equity stake in it. The risk to taxpayers from this investment would be acceptable, however, once the banks are freed of their toxic assets. A clear emphasis that the government stake is temporary would also be necessary. The government would cover the bad bank's losses, while profits would be distributed to the 
distressed bank's current shareholders. Either a separate bad bank can be created for each systemically relevant banking institute, or one central bad bank with a separate account for each institute. Under the terms of our proposed plan, bad banks and nationalization are not alternatives but rather two sides of the same coin. Although we refer mainly to the German situation, the elements of the plan will work in other countries as well.

The rest of the paper is organized as follows. Section 2 evaluates the situation of German banks in terms of capitalization. In section 3, bad bank solutions of the past are studied and prerequisites for success are examined. Section 4 develops a classification scheme for existing and planned bad bank solutions. We develop in Section 5 the efficient design for a public bad bank. Section 6 evaluates the German Government's bad bank proposal. Section 7 concludes. Two simple numeric examples illustrate the working of both bad bank plans in the Appendices.

\section{Weak Capital Basis of German Banks}

The capital bases of German banks are seriously endangered by the high quarterly write-down of asset values. A lasting return of confidence cannot be expected without the removal of the troubled securitized assets plaguing the system, which largely have their origin in the US mortgage markets. Figure 1 displays equity capital to assets and core capital ratios (in percent) for a selection of large banks. Figure 2 displays this data for a selection of German federal state banks (Landesbanken). Some of these banks have already accepted government assistance in order to stay above the minimum core capital ratio of 4 percent. $^{b}$

According to the Bundesbank, the total capital including reserves held by all German banks is approximately 415 billion euros. ${ }^{\mathrm{c}}$ Estimates of the total incurred losses from toxic assets vary at present between 200 and 300 billion euros - in other words, between 8 and 12 percent of German GDP. The president of the Federal Financial Supervisory Authority (BaFin)

\footnotetext{
${ }^{\mathrm{b}}$ Following the intensification of the financial crisis, many have advocated that a bank's core capital should comprise at least ten percent of its risk-adjusted assets. Financial experts view an equity capital to assets relationship of 4 to $5 \%$, and thus a leverage ratio of $25: 1$ and 20:1, as acceptable for a credit institute. In recent years, leverage ratios of 30:1 for hedge funds have been normal. Nine months before it was shut down by the government in January 1998, the US hedge fund Long Term Capital Management had a leverage ratio of 25:1 (see https://treas.gov/press/releases/reports/hedgfund.pdf, p.12).

${ }^{c}$ Consolidated balance sheet for German monetary financial institutions (MFIs) from the German central bank's European System of Accounts (see http://www.bundesbank.de/download/statistik/bankenstatistik/S101ATIB01013.PDF).
} 
recently amounted toxic assets in German banks' balance sheets to 180 to 200 billions euros. $^{\text {d }}$ During the Swedish bank crisis in the early 1990s, write-downs amounted to more than 12 percent of GDP. Losses of this magnitude - by no means unrealistic in the present crisis - would seriously erode the capital bases of German banks.

\section{(Figure 1 about here)}

The worsening capital position of the banks has a number of consequences with destabilizing feedbacks for financial markets and the real economy. Regulatory authorities in Germany are forced to close a bank if its core capital quota falls below 4 percent. The threat of imminent bank closures is a source of insecurity for market participants and isolates the affected banks from capital flows. In addition, banks are forced to limit the amount of credit they provide if they lack the necessary equity capital. This increases the chances that companies outside the banking sector will have excessive difficulty obtaining credit for their operations. The US savings \& loan crisis in the 1980s demonstrated that under the threat of bankruptcy, managers of over-indebted banks are prone to risky behavior in attempt to rescue their institutions from failure. ${ }^{e}$ Such risky behavior is known as "gambling for resurrection". It is encouraged by the fact that limited liability saves bank managers from incurring potential losses themselves. ${ }^{\mathrm{f}}$

\section{(Figure 2 about here)}

\section{The Bad Bank Solution}

The creation of one or more bad banks represents a way of overcoming this dilemma. ${ }^{\mathrm{g}} \mathrm{A}$ bad bank purchases or takes over troubled loans or securities and then attempts to restructure and manage these assets in a way that maximizes their value. Once the banks are freed from troubled assets and the need to constantly write down asset values, the negative effects

\footnotetext{
${ }^{\mathrm{d}}$ Markus Zydra, Sanio warnt und droht, Süddeutsche Zeitung, 20.05.2009.

e cf. Federal Deposit Insurance: The Banking Crises of the 1980s and Early 1990s: Summary and Implications, www.fdic.gov/bank/historical/history/3 85.pdff, see http://www.fdic.gov/bank/historical/history/ (last update 6/5/2000).

${ }^{\mathrm{f}}$ Freixas, X., B. M. Parigi, J.-C. Rochet. 2003: The Lender of Last Resort: A 21st Century Approach, Working Paper Series 298, European Central Bank.

g Zimmermann, K. F. 2009: Letzter Ausweg bad bank? Commentary in DIW Berlin Weekly Report No. $6 / 2009$.
} 
associated with the threat of bankruptcy, a reduction in lending due to a lack of capital, and the readiness to take risks at the expense of creditors and the general public can be minimized or eliminated. However, bad banks do have two drawbacks. First, capital is needed to create a bad bank - potentially in very large amounts. Second, there may be considerable losses at the end of a bad bank's life. Additional costs will result if the conditions for the purchase of toxic assets represent an incentive for banks to rely on government bailouts in the future. Historical examples show a wide spectrum of different variants of bad banks. The particular plan that is selected determines the current and future expenses borne by taxpayers when the bad bank is established.

\section{Historical Examples of Bad Banks}

The special handling of troubled assets is not uncommon in the day-to-day activities of the banking world. For example, non-performing corporate loans are typically transferred to a work-out department. ${ }^{\mathrm{h}}$ In the case of large loan amounts, the individual lenders form creditor pools in order to prevent coordination failures and a sudden withdrawal of lenders that can force a financially distressed firm into bankruptcy. ${ }^{i}$ In the past, work-outs have often resulted in loans being converted into share capital. ${ }^{\mathrm{j}}$ A bad bank is essentially a work-out department on a much larger scale. When the illiquid assets on the banking industry's books endanger the entire financial system, a bad bank has often been the solution of choice.

At the end of the 1980s, more than 1,000 savings \& loan institutions in the United States were threatened by insolvency due to financing with divergent maturity dates in connection with high interest rates for depositors but comparatively low rates on mortgage lending. ${ }^{k}$ In 1989 , the Resolution Trust Corporation (RTC) - a bad bank - was founded. The RTC was set up with government funding and to a limited extent with money from private investors. Between 1989 and 1995, the RTC took over 747 bankrupt S\&Ls with a book value of 394 billion

\footnotetext{
${ }^{\text {h }}$ Schäfer, D. 2002: Restructuring Know How and Collateral, Kredit und Kapital 35, pp 572-594.

i Brunner, A. and J. P. Krahnen. 2008: "Multiple Lenders and Corporate Distress: Evidence on Debt Restructuring”, Review of Economic Studies 75(2), pp. 415-442. Hubert, F. and D. Schäfer. 2002. "Coordination Failure with Multiple Lending, the Cost of Protection Against a Powerful Lender",. Journal of Institutional and Theoretical Economics 158(2), p. $256 \mathrm{ff}$.

${ }^{j}$ Schäfer, D. 2003: "Die „Geiselhaft“ des Relationship-Intermediärs: Eine Nachlese zur Beinahe-Insolvenz des Holzmann-Konzerns", Perspektiven der Wirtschaftspolitik, 4(1), pp. 65-84.

${ }^{\mathrm{k}}$ More than 1,600 banks went bankrupt or required government assistance between 1980 and 1994.
} 
dollars. The S\&L bailout cost US taxpayers a total of 124 billion dollars, 76 billion of which fell to the RTC. ${ }^{1}$

In the early 1990s, Sweden attempted to master its banking crisis with several asset management companies. The two most important bad banks - Securum and Retriva - were set up by the Swedish government. Some 3,000 non-performing loans that had been extended to 1,274 troubled companies were transferred from Nordbanken - which had been completely taken over by the government - to Securum. This corresponded to 21 percent of the bank's asset portfolio. Retriva, for its part, took over $45 \%$ of Gota Bank's assets shortly after the bank was nationalized. ${ }^{\mathrm{m}}$

Nordbanken, which took over Gota Bank in 1993, is known today as Nordea Bank, of which the Swedish government still holds a $19.9 \%$ stake. $^{\mathrm{n}}$ In 2007, the revenues from several sources, dividends, selling of stock and a rising value of the government's remaining equity stake, finally offset the cost of the bailout. That the bailout eventually paid for itself is attributable to the success of Sweden's bad bank plan in minimizing losses on troubled assets. $^{\circ}$

In 2001, a Berlin based bank holding company known as the Berliner Bankgesellschaft was threatened with bankruptcy due to the returns it had guaranteed to real-estate fund investors. The city-state of Berlin prevented the closure of the holding company which also owned Berlin's federal state bank (Landesbank) and savings bank (Sparkasse) - by taking control of it and providing credit guarantees worth over 21.6 billion euros. ${ }^{p}$

\footnotetext{
${ }^{1}$ Curry T. and L. Shibut. 2000: The Cost of the Savings and Loan Crisis: Truth and Consequences, FDIC Banking Review, www.fdic.gov/bank/analytical/banking/2000dec/brv13n2_2.pdf.

${ }^{\mathrm{m}}$ Ingves, S. and G. Lind. 1996: The Management of the Bank Crisis - in Retrospect, Quarterly Review Sveriges Riksbank 1/1996, pp. 5-18.

${ }^{\mathrm{n}} \mathrm{See}$ http://www.nordea.com/Investor\%2bRelations/Nordea\%2bshare/Shareholders/85732.html (access on the $5^{\text {th }}$ of May 2009).

${ }^{\circ}$ Ketzler, R. and D. Schäfer. 2009: Nordische Bankenkrisen der 90er Jahre: Gemischte Erfahrungen mit „Bad Banks", DIW Berlin Weekly Report No. 5/2009, pp 87-99.

${ }^{\mathrm{p}}$ The city-state of Berlin provided $87.5 \%$ of the necessary capital increase of 2 billion euros. Berlin thus increased its stake from $56.6 \%$ to $80.95 \%$. Parion, an insurer, saw its stake reduce following the capital increase to $2.27 \%$ (from $7.5 \%$ ). The percentage of free-floating shares fell from $15.89 \%$ to $5.93 \%$ following the capital increase.

www.manager-magazin.de/unternehmen/artikel/0,2828,160057,00.html.
} 
In 2006, the newly founded Berliner Immobilien Holding (BIH) took over several troubled real-estate funds. ${ }^{\mathrm{q}}$ The former Berliner Bankgesellschaft was thus effectively separated into a bad bank (BIH) and good bank (Landesbank Berlin). In 2007, the city-state of Berlin managed to sell its $81 \%$ stake in the Landesbank Berlin for 4.7 billion euros. BIH has hitherto invested some two billion euros in the re-purchase of shares and the refurbishment and improvement of its properties. ${ }^{r}$ Additional investments are planned. The goal is to make its property inventory so attractive that potential buyers will be willing to take over the guarantees provided by Berlin.

Yet in recent years, ailing institutions have also made use of bad banks as a method for repairing the balance sheets without governmental interference. Between 2003 and 2005, Dresdner Bank transferred 35.5 billion euros in toxic loans and shares which had lost strategic relevance to a so-called Institutional Restructuring Unit (IRU). ${ }^{\mathrm{s}}$ In 2008, WestLB, the Landesbank partially owned by the state of North Rhine-Westphalia, founded a consolidation vehicle named "Phoenix" in Dublin, Ireland. As an off-balance-sheet special purpose vehicle (without a banking license), Phoenix has already taken over assets with a book value of 23 billion euros. The owners have guaranteed these assets for five billion euros. ${ }^{t}$

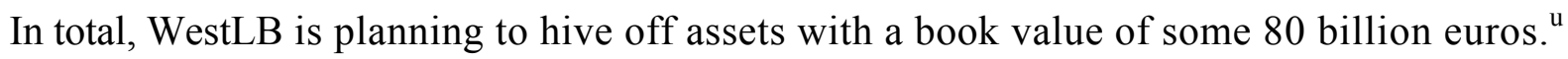

\section{Prerequisites for the Success of a Bad Bank}

Realistically, it must be assumed that a bad bank will produce a loss in the end. If these losses remain low, they can be more readily compensated for by an appreciation in value in other areas - for example, through the increased worth of a government stake in the rescued banks.

\footnotetext{
q According to an article in the February 2007 issue of the German magazine "Berliner Wirtschaft," the takeover was finalized for the symbolic sum of one euro. The takeover included 29 closed funds with an original investment value of approximately 10 billion euros and more than 500 properties. The holding company had 26 employees including managers, while the real-estate investment companies controlled by the holding company employed a total of 517 people, www.bih-holding.de/bih/aktuelles/BlnWirtschaft BIH Febr2007.jpg

${ }^{\mathrm{r}}$ cf. Börsen-Zeitung dated October 2, 2008. Berlin startet Verkauf der BIH Immobilien Holding, Investmentbank gesucht - Altlast der Bankgesellschaft.

${ }^{\mathrm{s}}$ http://www.dresdner-bank.de/dresdner-bank/presse-center/

${ }^{t}$ Communication from the Commission on the Treatment of Impaired Assets in the Community Banking Sector, Annex 2, http://ec.europa.eu/competition/state aid/legislation/impaired assets.pdf

u According to Irish press reports, Dublin was selected due to tax considerations and the local availability of financial and restructuring expertise.
} 
The government has a good chance of recouping its investment in a bad bank if the following prerequisites are fulfilled:

- Troubled assets have been purchased/taken over at a low price

- Active management of these assets is possible

- Financial experts are involved who know how to deal with such assets

- Time is available

- A clear governance structure has been implemented

If a market price for an asset does not exist, then the bank being relieved of the asset has an informational edge over the buyer. In this state of affairs, "lemon market" effects are likely. An ailing bank will only transfer assets to a bad bank which have a value below the agreedupon average price. ${ }^{\mathrm{V}}$ As a result, the bad bank pays inflated prices and generates losses. In this scenario, an excessive burden is also borne by the taxpayer in the recapitalization of the banking sector.

The restructuring of the acquired assets requires active management. This includes conducting negotiations with debtors, debt rescheduling and, if necessary, debt reductions in order to avoid default. Clearly identifiable and accessible partners in the negotiation process are thus essential for the effective management of troubled assets.

Another key element in this regard is the creation of attractive investment packages for potential buyers, possibly with government financial support. If the government does not have sufficient access to specialized knowledge for the effective restructuring and management of assets, taxpayers may be forced to cover disproportionately high losses, despite a purchase price that accurately reflects the underlying value of the illiquid assets. Generally, the acquisition of financial experts for the formation of a bad bank is no simple task, as there is a shortage of individuals with the requisite expertise, even at the international level. The pool of individuals with experience in managing troubled assets is small. ${ }^{\mathrm{w}}$

\footnotetext{
v Akerlof, G. A. 1970: "The Market for 'Lemons': Quality Uncertainty and the Market Mechanism", Quarterly Journal of Economics 84(3), pp. 488-500.

${ }^{\mathrm{w}}$ The shortage of qualified experts is demonstrated by the recurrent involvement of Jan E. Kvarnström, the former director of the Swedish bank Securum. He managed Dresdner Bank's IRU; according to press reports, worked on behalf of the German government to manage the sale of KfW's stake in IKB; and helped to manage six billion euros in structured securities held by IKB, cf. von Buttlar, H. and N. Luttmer. 2009: Der schwedische Bankenlotse, Financial Times Deutschland, 24 January.
} 
Fire sales to cover a shortage of liquidity may place downward pressure on asset prices and minimize sale proceeds. If a bad bank lacks sufficient capital to wait for an opportune moment to sell its assets, it will incur unnecessarily high losses. Excessive costs for taxpayers can also be expected if a clear governance structure has not been defined (for decision-making, monitoring and accountability). The executive managers in charge of a bad bank should be able to conduct operations and make decisions regarding the sale or restructuring of assets autonomously, and without being absorbed by issues that only arise because of conflicts of interest between the government and banks.

\section{Methods of Capitalization and Organizational Structure}

The amount of capitalization required by a bad bank is essentially determined by two factors: operating costs and acquisition costs. When a low price is paid for the acquired troubled assets, this not only minimizes the risk of future losses but also keeps the initial capital requirements of the bad bank low.

The source of financing determines whether the government or private sector provides the required start-up funding. The need for liquid funds depends on how the banks being freed of their troubled assets will be "paid." Liquid funding is not immediately required if a "payment" is made with government securities. However, in this regard the amount of the write-downs and a possible need to re-capitalize the bank are contingent upon whether the book value of the distressed assets exceeds the book value of the government securities provided in exchange.

If the government provides 100 percent of the financing - whether in the form of liquid capital or government securities - future losses suffered by the bad bank must be borne first by the taxpayer. The greater the amount paid initially for the troubled assets, the higher the risk of future losses. The participation of the private sector in absorbing these losses can be achieved through negotiation once the bad bank's final operating result is forthcoming. Alternatively, fixed terms for the distribution of losses can be agreed upon in advance. Such terms cannot foreclose all possibility of future renegotiation, however. In this way, the government is 
subject to the hold-up problem. This latent threat of potential ex post exploitation rises in direct relation to the amount of funding initially provided to establish the bad bank. ${ }^{\mathrm{x}}$

A bad bank plan can be implemented in a centralized or decentralized manner. Under a decentralized plan, each troubled bank is split into its own good and bad bank. Under a centralized plan, all distressed assets in the banking sector are deposited in a single bad bank. If one bad bank were established for each of the three main pillars of the German banking industry - i.e. for the credit unions, savings banks and private banks - this would also qualify as a centralized bad bank plan. Mixed solutions that combine private and public sector funding as well as centralized and decentralized organizational features are also conceivable.

\section{Classification of Historical Precedents and Proposed Models}

The Table below organizes known bad bank examples and current proposals according to the source of capitalization and organizational form. As the Table shows, the majority of known bad banks have been established based on a decentralized organizational model. Retriva and Securum (Sweden) as well as BIH (Berlin) were founded through the subdivision of a bank threatened with insolvency into a good and bad bank. In all three of these cases, the government provided the funding for the bad bank and also recapitalized the good bank in exchange for a shareholder stake.

In each case, the distressed assets were also transferred to the bad bank in a single transaction. This effectively circumvented the need to engage in subsequent negotiations for the distribution of bailout costs. At the same time, a government stake in the good bank is necessary for losses to be recouped and for the possibility of a net taxpayer gain, or at least to break even, further down the road.

(Table about here)

\footnotetext{
"The "hold-up problem" is a term that is known from contract theory and from behavioral finance. See Williamson, O. E. 1979: "Transaction-Cost Economics: The Governance of Contractual Relations", Journal of Law and Economics 22(2), pp. 233-62.
} 


\section{Successful historical examples}

Sweden's bad banks, Securum and Retriva, managed to limit losses on non-performing assets. A successful resolution also appears to be on the horizon for Berliner Immobilien Holding. ${ }^{y}$ With the application of the principle that the stockholders should bear losses first, it was possible to secure relatively low prices for the acquired assets. This circumvented potential "lemon market" effects. At the same time, there were no incentives established for shareholders to rely on the expectation of government assistance in the future. The partners involved in negotiations for the restructuring of the troubled assets were clearly identifiable and accessible, ensuring that assets could be managed actively and effectively. In Sweden and Berlin, the government drew on the expertise of external consultants with distressed asset management experience. The allocation of sufficient funding prevented the premature sale of assets at prices below their future market value. As both the good and bad banks were partially or completely in government hands in each case, no conflict of interest developed between the government and private banks. For this reason, it can be assumed that the management had considerable autonomy over operative decisions.

\section{Proposed Models for the Current Crisis}

The gray boxes designate proposed models for the current crisis. As the table shows, the proposals under discussion are all of a "mixed" form. In the US, the Geithner plan relies on public-private partnerships for the purchase of toxic assets. The original US plan foresaw the creation of a central fund for the acquisition of distressed assets. The latest proposals involve numerous funds with mixed financing. Economists have recently suggested that funds should compete with each other to acquire assets from individual banks and government share capital. $^{\mathrm{z}}$

The German government's bad bank plan proposes a special purpose vehicle (SPV) for each participating bank. The SPV would transfer government bonds at some discount to the

\footnotetext{
${ }^{y}$ The amount of money still to be invested in order to make the properties of BIH attractive enough for potential buyers is estimated to remain lower than the proceeds from the sale of Landesbank Berlin.

${ }^{z}$ Bebchuk, L. 2009: Buying Troubled Assets, Discussion Paper No 636, 4/2009, John M. Olin Center for Law, Economics, and Business. Harvard Law School, and Bebchuk, L. 2009: Jump-Starting the Market for Troubled Assets, www.forbes.com/2009/03/03/troubled-assets-relief-opinions-contributors_bad_bank.html.
} 
participating bank in exchange for the toxic assets (see Section 6 for a detailed discussion). The proposal made by the Association of German Banks (BdB), in which an account would be set up for each bank in need of assistance, is aimed at establishing a government-funded bad bank with a mixed organizational structure. It must be noted, however, that mixed solutions are particularly susceptible to conflicts of interest and unclear governance structure.

\section{Efficient Design for a Public Bad Bank}

\section{Objectives}

A public bad bank must be in a position to address numerous challenges. First, the transparent removal of troubled assets is necessary in order to ensure that the rescued bank has real prospects for a fresh start. Second, the costs of the bailout for the taxpayer should be minimized. Third, no incentives or new opportunities for opportunistic behavior in the future should be created. To do this, the implemented bad bank model should limit the potential for "hold-up" problems while emphasizing to shareholders and executives that entrepreneurial failure is a real possibility.

The toxic assets currently plaguing the German banking system are for the most part complex mortgage-backed securities originating in the US housing market. The anonymity of the USbased original borrowers and the large number of intermediate institutions involved in the packaging and onward sale of these securities represent serious impediments to the identification of the relevant counterparties for debt restructuring. Hence, there are fewer instruments available for restricting the bad bank's losses than in the past. Basically, the tools are limited to the purchase price, the securing of additional time to sell assets at an opportune moment and the governance structure.

\section{Key Elements of the Bad Bank Design}

The selected bad bank plan should consist of the following key elements in order to address the challenges: 
- Troubled assets should be valued based on current market prices prior to their takeover by the bad bank. Troubled assets for which there is no market should be transferred to the bad bank at a zero price and therefore at zero cost for the government as the bad bank's sponsor.

- The government should recapitalize the rescued bank (the remaining good bank) through the acquisition of a shareholder stake; in extreme cases, the remaining good bank should be taken over by the government.

- The bad bank should be funded by the government. External experts should be entrusted with the management and future sale of the troubled assets at the government's expense. If a profit remains after the proceeds from holding the troubled assets until expiration date and/or selling them to the market have materialized and operating costs have been deducted, these profits should be distributed to the former shareholders.

- The government should announce its commitment to the future re-privatization of its stake in the rescued bank. When establishing a bad bank, the government should make a binding commitment to how long it has to sell its shares in the good bank following the closure of the bad bank.

- All "systemically relevant" banks should be identified and required to participate in the plan.

The takeover of toxic assets by the government at zero cost and the corresponding write-down of assets will create transparency, avoid the high expense of pricing distressed assets, and will insure that shareholders are the first ones to bear the cost of failure. ${ }^{\text {aa }}$ The risk of moral hazard will also be effectively limited. A zero-cost acquisition is also justified based on the fact that the active management of the troubled assets is impaired by their complex structure. This approach will also keep the bad bank's initial capital requirements at a minimum.

With the value of their toxic assets written down to zero, a number of banks will no longer meet the legislated core capital requirement. The government should take a stake in these banks in order to recapitalize them. The prior removal of troubled assets will limit the risk taken on by the government and provide good prospects for the appreciation of its investment.

\footnotetext{
aa The European Commission has proposed valuing the troubled assets prior to their transfer on the basis of their inherent value. This would be a very difficult task, however, due to the complexity of the assets. Communication from the Commission, 1.c.
} 
The government's risk of loss (through the bad bank) and opportunity for success (through the rescued good bank) would thus be clearly separated from one another. This would also contribute to transparency.

The government should bear the costs of running the bad bank and ensure that sufficient capital is available so that assets can be held until their date of maturity or an opportune moment for their sale. The risk of exploitation for the party providing the initial capital would be limited by the acquisition of the assets at zero cost. The rule that profits of the bad bank should be returned would ensure that the former shareholders are not forced to suffer any unfair losses from the transfer of the troubled assets to the bad bank. ${ }^{\text {bb }}$ In addition, proceeds from the resale of the government's stake in the rescued bank would be used to cover the taxpayer's initial investment for recapitalizing the good banks and for possible losses incurred by the bad bank. In this case, the government would have no incentive to delay the resale of the stake it had taken in the rescued bank. Appendix 1 shows a simple example of how the proposed design would work.

At the very most, the amount of funding that the government will need to provide to recapitalize the banking sector will equal the losses that accrue from the write-down of troubled assets - i.e. somewhere between 200 and 300 billion euros for Germany. The oneoff set-up costs and annual operating costs for the bad bank have to be added to this.

\section{German Landesbanken}

The proposed design for a bad bank provides the opportunity of solving the long lasting problem of too many weak Landesbanken in Germany. These publicly owned regional banks are particularly affected by the financial turmoil. The majority of them is extremely debtridden and lacks a reliable business model.

Under the plan, a depreciation of the toxic assets' book value according to their zero market value reduces initially the equity of the Landesbanken shareholders - the federal states and the savings banks. A centralized bad bank created by the German government for all ailing

\footnotetext{
bb This idea also forms the basis of the debtor warrant in the Bundesbank's proposed model. If the shareholders have in fact surrendered the assets at a price lower than their market value, they can recover the difference through a debtor warrant.
} 
Landesbanken takes over the toxic products at a value of zero - and provides for further exploitation at its own expense. Each Landesbank has a separate account at the bad bank. At the same time, the German government recapitalizes the remaining good banks, if possible together with the savings banks. In extreme cases, this operation can result in a complete takeover by the consortium of the German government and the savings banks. If the savings banks contribute to the recapitalization of the good Landesbanken, they receive a pre-emption right for the government's shares. If the savings banks are not available as an investor, the funds for the recapitalization have to come completely from the government. Deficits of the bad bank shall be borne by the German government; surpluses are transferred to the current shareholders, i.e. the federal states and the savings banks.

The good banks merge under pressure of their shareholders to one institution. If, after the end of the crisis, the pre-emption right is exercised, the savings banks take over the merger completely. The savings banks may have a strong incentive to become the majority owner. They are in need of a central institution and a clearing agent for their own operations. If the pre-emption right is not exercised, the government can privatize its shares without restrictions to private, co-operative or foreign-based banks.

Currently, at least four out of the seven Landesbanken are severely distressed. The German savings banks association already owns almost 100 percent of the Landesbank Berlin Holding $\mathrm{AG}$, one of the three Landesbanken that are less affected by the crisis. If the savings banks took over the merger, the total number of remaining Landesbanken could be reduced to two. The same number of Landesbanken would evolve if the merger were sold to other banks. In the long run, the remaining two Landesbanken should also be privatized.

\section{The Bad Bank Plan of the German Government}

The German government's bad bank program follows a different agenda than the above proposed design. The two central principles of the proposed design are the provision of a fresh start and the spending of taxpayers' money only for shares of the good banks. Immediate disclosure and write-off of structured products related to sub-prime mortgages is indispensable for this purpose. Systemically relevant banks would be forced to become part of the program, 
depreciate and restore their capital basis. Using government money for restoration is compulsory if private funds are not available.

In contrast, in the government's bad bank plan, government bonds are used to compensate the bank for the transfer of the toxic assets to the bad bank. These bonds burden the taxpayers' with future debt owned by the participating bank. In addition, the program allows for the distribution of the losses over time and for a voluntary participation.

If a bank participates it would establish a special purpose vehicle (SPV) - a bad bank - that does not require a banking license. The SPV receives the troubled securities at a 10 percent discount from the book value. The discount would be reduced if the write-offs cut the core capital ratio to a level below 7 percent. In return the SPV would transfer a bond in the amount of the discounted book value to the bank. The state, via its bank rescue fund SoFFin, would guarantee the value of the bond at some cost to the bank. On behalf of the state, SoFFin would charge a fee for this insurance service. The secure bonds do not qualify as risk-weighted assets, and can be pledged as collateral in exchange for a new credit from the ECB.

Independent experts (e.g. accountants) would determine a so-called fundamental value in a two-step procedure. In the first step, the present value of the assets is derived based on expected future cash flows. From this value, a premium is deducted, ${ }^{\mathrm{cc}}$ presumably, to cover for the risk of false valuation. The fundamental value would need confirmation by the banking supervisory authority. ${ }^{\text {dd }}$ The bank is indebted to the SPV in the amount of the difference between the transfer value and the fundamental value. This debt is worked off by annuity payments over a period of 20 years at maximum. If the bank has not enough cash earnings it can compensate the SPV by shares.

At closure date the bank receives cash as the SPV pays off the government bond. If the SPV would produce a loss in the end ${ }^{\mathrm{ee}}$, either because the default risk of the structured products turned out higher than originally assumed, or because the assets were sold at a price below the fundamental value, the bank's future earnings would go to the fiscal budget until the deficit is

\footnotetext{
${ }^{c c}$ Ministry of Finance, Entwurf eines Gesetzes zur Fortentwicklung der Finanzmarktstabilisierung http://www.bundesfinanzministerium.de/nn 69116/DE/BMF Startseite/Aktuelles/Aktuelle Gesetze/Gesetzent wuerfe Arbeitsfassungen/130509 Entw BadBank.html? nnn=true (access on the 22 ${ }^{\text {nd }}$ of May 2009)

dd Either the Federal Financial Supervisory Authority (BaFin) or the Bundesbank, or both institutions may be in charge.

${ }^{e e}$ The SPV would be liquidated after the asset with the highest maturity has expired, or, alternatively, the last asset has been sold.
} 
balanced. Possible gains of the SPV would be redistributed to the common equity shareholders. Appendix 2 shows a simple example that illustrates how the German government's bad bank plan works in principle.

Our proposed design and the government's plan coincide if the fundamental value is set to zero, and if the differential payment would be due immediately. In this case, the bad bank would become shareholder of the good bank to the extent the bank hands over shares to the SPV. In line with our bad bank design the taxpayers' hold-up risk would then be zero. In contrast, a high fundamental value implies that the mass of the taxpayers' compensation for handing over secure bonds is prolonged for at least 20 years. Future contingencies may render the enforcement of the intended gradual loss realization by shareholders a difficult task. Because of this enforcement problem, the taxpayers' risk of being held-up remains high.

In theory the fundamental value in the government plan does not determine the amount of subsidies that ailing banks receive (see the equal total losses in terms of present values for shareholders in both examples shown in the Appendices). However, the supposed zero impact on the taxpayers' total engagement may create an incentive for external experts to value the toxic assets too high.

In contrast to our concept the government's bad bank plan implies a balance sheet extension beyond the original amount. Public recapitalization of the bank is not intended. Thus, in the absence of private funds for additional equity capital, a participating bank would need to finance new business loans by issuing new debt. Such balance sheet extension reduces the core capital ratio. However, a weakening capital basis creates its own problems for regaining stability in the banking sector. There is the expectation that investors and depositors want banks to strive for a higher core capital ratio instead for a lower one. Thus, it remains an open question whether participating banks would indeed increase lending under the government's bad bank plan. In addition, imagine that in the course of building the new financial market architecture, the Basel II framework was adjusted in a way that a bank's leverage affects the capital requirements. Such adjustment would at least partly neutralize the intended unlocking of equity capital, and would create additional pressure to recapitalize banks.

Another problem is that the German government intends to make the bad bank plan optional. Systemically important banks may gamble for resurrection in the sense that they dump the bad 
bank plan in order to avoid disclosure of losses and simply hope for better times. However, with such behavior, uncertainty would remain in the market as neither the value of assets nor the amounts of hidden losses of some large banks were disclosed. The comeback of trust into the business models of the banking sector would most likely be undermined.

Finally, the lacking intention of the central government to become a shareholder of the ailing Landesbanken is a severe obstacle to their consolidation. Mergers can be achieved much more easily if the party with the strong will to arrange the merging has also a strong shareholder position in the merger targets. However, in contrast to our own bad bank plan, the German government's plan fails to provide for an instrument that brings the central government in a strong shareholder position.

\section{Conclusion}

Under the terms of the plan, a bad bank and nationalization are not mutually exclusive alternatives but rather two separate policy options that complement one another. The plan avoids mixed proposals with unclear governance structures and uncertainties about the banks' capacity of raising a sufficient volume of capital. The question as to whether a single bank or multiple bad banks should be established is of secondary importance provided the basic plan selected ensures that: (1) distressed banks are freed of troubled assets and are given a fresh start; (2) the taxpayer is not unnecessarily burdened; and (3) moral hazard and other negative incentives are avoided. Furthermore, in order to provide a foundation for the rescued banks to pursue a sustainable business model, a new regulatory framework for capital markets must be enacted.

Historically, most bank plans have followed a decentralized model (i.e. multiple bad banks). The total assets of the systemically relevant banks currently impacted by the crisis and the oftcited heterogeneity of the toxic assets plaguing the system also lead to the belief that no benefits of scale would be gained by a centralized bad bank solution. To implement the plan and bailout the banking system, the government will need a considerable volume of capital immediately, which is the primary drawback of our proposed plan. 
The implementation of a bad bank plan has to go hand in hand with building a new financial market architecture. The boundary problem in the financial sector ${ }^{\mathrm{ff}}$ implies that banks may stop supporting a new regulatory framework as soon as bad banks are created and their balance sheet problems are solved.

Figure 1

Selected Commercial Banks

Ratios in percent

\footnotetext{
${ }^{\mathrm{ff}}$ Brunnermeier, M., Crockett, S., Goodhart, C. Persaud A, and Shin, H. (2009), The Fundamental Principles of Financial Regulation. Geneva Report on the World Economy.
} 


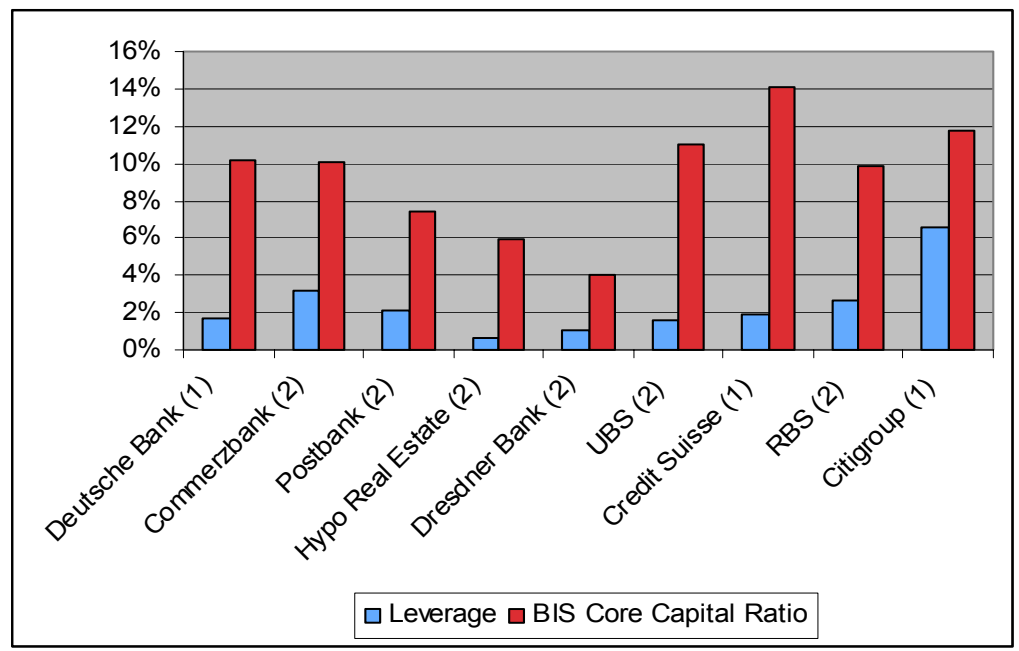

Notes: 1 Reporting date: 31 March 2009; 2 Reporting date: 31 December 2008

Leverage is measured as equity capital to assets.

Source: Data compiled by the German Institute for Economic Research (DIW) based on the most recent available financial statements DIW Berlin 2009.

\section{Figure 2}

German Federal State Banks (Landesbanken)

Ratios in percent

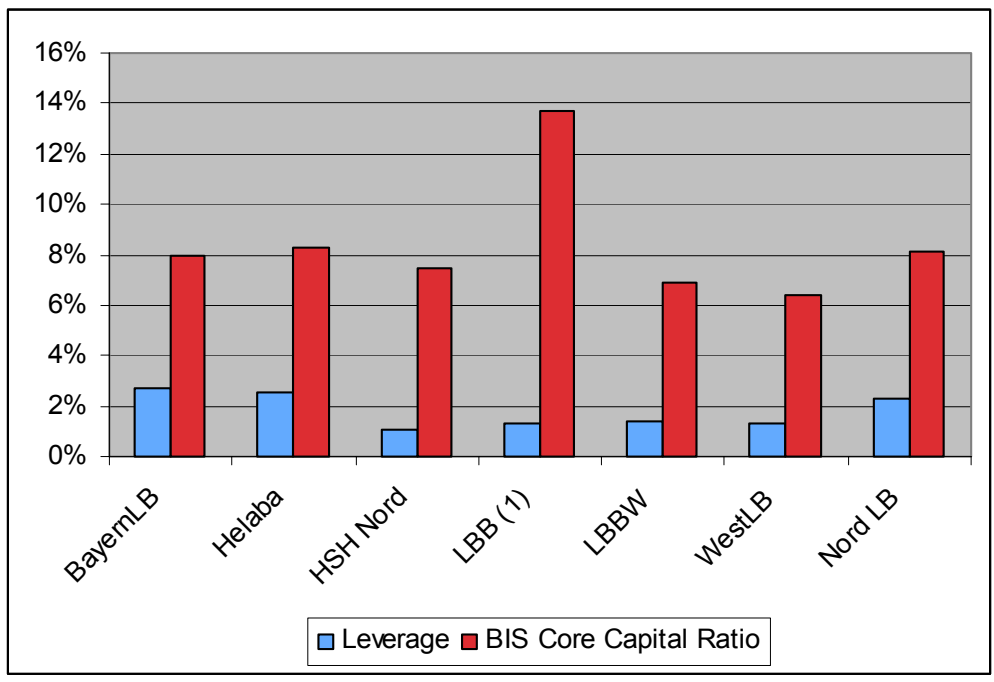

Notes: Reporting date is 31 December 2008; Leverage measured as equity capital to assets.

1 applies to RVG Group. The Landesbank Berlin (LBB) Holding, which is part of RVG group reported a core capital ratio of 8 percent in the first quarter of 2009. The acquisition company of savings banks (SErwerbsgesellschaft) acquired the LBB Holding jointly with its partners Regionalverbandsgesellschaft $\mathrm{mbH}$ (RVG, general partner) and DSGV (limited partner) in 2007.

Abbreviations: Bayern LB = Landesbank of Bavaria, Helaba = Landesbank of Hessia and Thuringia, $\mathrm{HSH}$ Nordbank = Landesbank of Schleswig-Holstein and city state Hamburg, LBB = Landesbank Berlin, LBBW = Landesbank of Baden Wurttemberg, WestLB = Landesbank of North Rhine Westphalia, Nord LB = joint Landesbank of Lower Saxony, Saxony Anhalt and city state Bremen.

Leverage measured as equity capital to assets.

Source: Data compiled by the German Institute for Economic Research (DIW) based on the most recent available financial statements DIW Berlin 2009 
Table

\begin{tabular}{|c|c|c|c|}
\hline \multicolumn{4}{|c|}{$\begin{array}{l}\text { Classification of Bad Banks According to their Capital Source }{ }^{g g} \\
\text { and their Mode of Organization - Historical Examples and Proposals }\end{array}$} \\
\hline $\begin{array}{l}\text { Source of } \\
\text { Capital }\end{array}$ & Public & Mixed & Private \\
\hline \multicolumn{4}{|l|}{ Created as } \\
\hline $\begin{array}{l}\text { Centralized bad } \\
\text { bank (one bad } \\
\text { bank for all } \\
\text { ailing banks) }\end{array}$ & $\begin{array}{l}\text { USA - S\&L Crisis } \\
\text { 1989-1995: RTC }\end{array}$ & $\begin{array}{l}\text { Financial Market } \\
\text { Crisis } \\
\text { 2007/2008: } \\
\text { Public-private } \\
\text { Partnership (USA) } \\
\end{array}$ & \\
\hline $\begin{array}{l}\text { Mixed bad bank } \\
\text { (neither } \\
\text { centralized nor } \\
\text { decentralized) }\end{array}$ & $\begin{array}{l}\text { Financial Market Crisis } \\
\text { 2007/2008: } \\
\text { Bad bank model of the } \\
\text { Association of German } \\
\text { Banks: } \\
\text { Unique account for each } \\
\text { bank }\end{array}$ & $\begin{array}{l}\text { Financial Market } \\
\text { Crisis } \\
\text { e2007/2008: } \\
\text { nMultiple, competing } \\
\text { public-private } \\
\text { hpartnerships (USA) }\end{array}$ & \\
\hline $\begin{array}{l}\text { Decentralized } \\
\text { bad bank (an } \\
\text { ailing bank } \\
\text { creates its own } \\
\text { bad bank) }\end{array}$ & $\begin{array}{l}\text { Swedish Bank Crisis } \\
\text { 1992: } \\
\text { Securum, Retriva } \\
\text { Berlin - } 2001 \text { near insolvency } \\
\text { of "Berliner } \\
\text { Bankgesellschaft": BIH } \\
\text { Financial Market Crisis } \\
\text { 2007/2008: } \\
\text { Phoenix (WestLB) } \\
\text { Financial Market Crisis } \\
\text { 2007/2008: } \\
\text { German Government's } \\
\text { proposal }\end{array}$ & & $\begin{array}{l}\text { "Mini" Bank Crisis in } \\
\text { Germany, 2003/04 in } \\
\text { the aftermath of the } \\
\text { "new economy" bust } \\
\text { IRU (Dresdner Bank) }\end{array}$ \\
\hline \multicolumn{4}{|c|}{ Classification of Bad Banks According to the Way of Transfer } \\
\hline & \multicolumn{2}{|c|}{ Purchase/Takeover of toxic assets } & $\begin{array}{l}\text { Exchange of toxic } \\
\text { assets for secure } \\
\text { bonds }\end{array}$ \\
\hline
\end{tabular}

${ }^{g g}$ Capitalization is also classified as public if banks receive government bonds instead of money in exchange for toxic assets. Government bonds are simply an alternative way of financing the purchase of toxic assets. 


\begin{tabular}{|c|c|}
\hline $\begin{array}{l}\text { Swedish Bad Banks } \\
\text { Securum and Retriva } \\
\text { USA: RTC } \\
\text { Berlin: BIH }\end{array}$ & $\begin{array}{l}\text { German } \\
\text { Governments } \\
\text { proposal: } \\
\text { Government bonds } \\
\text { and } \\
\text { covering of losses by } \\
\text { shareholders over } \\
\text { time } \\
\text { Bundesbank } \\
\text { proposal: } \\
\text { Equalization claim } \\
\text { with debtor warrant } \\
\text { Association of } \\
\text { German Banks } \\
\text { proposal: } \\
\text { Gov. securities and } \\
\text { final accounting } \\
\text { with "fair distribution } \\
\text { of burdens" }\end{array}$ \\
\hline
\end{tabular}

Source: DIW Berlin 2009.

\section{Appendix 1: Example of how the proposed bad bank design works}

The following simple example illustrates how the proposed design of a bad bank plan works. Costs for establishing and running the bad bank are neglected for simplicity.

Assume that the bank has total assets of 1000 originally. Toxic assets amount to 100 . The rest are liquid assets. The bank has equity capital of value 100 and debt of value 900 (Table 1a). Note that all stocks and flows in the tables represent present values. 
Table 1a: Balance sheet of bank prior to the transfer of toxic assets

\begin{tabular}{|lr|rr|}
\hline Assets & Liabilities & 100 \\
\hline Toxic Assets & 100 & Equity (Core Capital) & 900 \\
\hline Liquid Assets & 900 & Debt & 1000 \\
\hline Total Assets & 1000 & Total Liabilities & \\
\hline
\end{tabular}

Table 1b: Write-off and recapitalization of the good bank

\begin{tabular}{|c|c|c|c|}
\hline Asset side & & Liability side & \\
\hline $\begin{array}{l}\text { Devaluation of assets } \\
\text { according to their zero } \\
\text { market value }\end{array}$ & -100 & $\begin{array}{l}\text { Reduction of Core Capital } \\
\text { (write-off) }\end{array}$ & -100 \\
\hline $\begin{array}{l}\text { New business loans (new } \\
\text { risk-weighted assets) }\end{array}$ & 90 & $\begin{array}{l}\text { Fresh equity capital from the } \\
\text { state }\end{array}$ & 90 \\
\hline Difference Total Assets & -10 & Difference Total Liabilities & -10 \\
\hline
\end{tabular}

Table 1c: Balance sheet of good bank post to the transfer of toxic assets and recapitalisization

\begin{tabular}{|lr|lr|}
\hline Assets & Liabilities & \\
\hline New business loans & 90 & $\begin{array}{l}\text { New Core Capital (held by the } \\
\text { state) }\end{array}$ & 90 \\
Liquid Assets & 900 & Original Debt & 900 \\
\hline Total Assets & 990 & Total Liabilities & 990 \\
\hline
\end{tabular}

Table 1d: Bad bank balance sheet prior to expiration (selling) date of toxic assets

\begin{tabular}{|c|c|c|c|}
\hline Assets & & Liabilities & \\
\hline Toxic Assets & 0 & Debt & 0 \\
\hline Total Assets & 0 & Total Liabilities & 0 \\
\hline
\end{tabular}

Table 1e: Bad bank's final balance sheet

\begin{tabular}{|lr|lr|}
\hline Assets & Liabilities & 50 \\
\hline $\begin{array}{l}\text { Selling price of Toxic } \\
\text { Assets }\end{array}$ & $\begin{array}{l}\text { Equity (=Gain distributed to } \\
\text { shareholders) }\end{array}$ & 50 \\
\hline Total Assets & 50 & Total Liabilities & \\
\hline
\end{tabular}

Total loss for shareholders: 50

The toxic assets with zero market price are written off completely (Table 1b). This step results in a complete wipeout of the ailing bank's capital basis (-100). If no private funds were available, the government would invest in shares of the good bank and restore the capital basis in the amount of 90 (Table $1 \mathrm{~b}$ and $1 \mathrm{c}$ ). The fresh equity capital of 90 can be used to grant new business loans. The balance sheet has contracted to the amount of 990 . 
The bad bank takes in the toxic assets without being subject to future payment obligations (Table 1d). Imagine that the selling price of the toxic assets (or alternatively, the true value of the received total cash flows) turns out to be 50 . Then, the final balance sheet of the bad bank (Table 1e) would show a gain of 50 to be distributed to former shareholders. Thus, the total loss of shareholders amounts to 50. Privatization of the government's shares in the good bank would compensate the taxpayer for providing the funds for recapitalization in the amount of 90. Note that the assumed toxic assets' true value of 50 percent is a fairly high number. The ECONOMIST, for example, reported that Merrill Lynch received in July 2008 only 22 cents on the dollar for a portfolio of Collateralized Debt Obligations (CDOs ) from hedge fund Lone Star. ${ }^{\text {hh }}$

\section{Appendix 2: Example of how the German government's bad bank plan works}

The following analogous example illustrates how the German government bad bank plan works in principle. The original balance sheet of the ailing bank is equivalent. Note that the government invests again the amount of 90 for rescuing the bank. However, in the German government's plan the state uses the funds to compensate the bank for giving up their toxic assets.

\footnotetext{
hh Thain Takes the Pain, THE ECONOMIST, July 31, 2008. In addition, Merrill Lynch had to finance 75 percent of the deal by loans to the assets' buyer.
} 
Table 2a: Balance sheet prior to the transfer of toxic assets

\begin{tabular}{|lr|lr|}
\hline Assets & Liabilities & \\
\hline Toxic Assets & 100 & Equity (Core Capital) & 100 \\
Liquid Assets & 900 & Debt & 900 \\
\hline Total Assets & 1000 & Total Liabilities & 1000 \\
\hline
\end{tabular}

Table 2b: Adaptions of balance sheet items after adopting the bad bank pla।

\begin{tabular}{|c|c|c|c|}
\hline Asset side & & Liability side & \\
\hline \multirow[t]{3}{*}{$\begin{array}{l}\text { Discount prior to exchange by } \\
\text { bonds }\end{array}$} & -10 & $\begin{array}{l}\text { Reduction of Core Capital } \\
\text { (write-off) }\end{array}$ & -10 \\
\hline & & $\begin{array}{l}\text { Reduced book value minus } \\
\text { fundamental value }\end{array}$ & -30 \\
\hline & & $\begin{array}{l}\text { New debt for paying the } \\
\text { difference: payment over } \\
20 \text { years as annuity }\end{array}$ & 30 \\
\hline Difference Total Assets & -10 & Difference Total Liabilities & -10 \\
\hline
\end{tabular}

Table 2c: Balance sheet post to the transfer of toxic assets

\begin{tabular}{|lr|lr|}
\hline Assets & & Liabilities \\
\hline $\begin{array}{l}\text { Bonds with reduced book } \\
\text { value } \\
\text { Liquid Assets }\end{array}$ & 90 & Remaining Core Capital & 60 \\
& 900 & Original debt & New debt \\
\hline Total Assets & 990 & Total Liabilities & 30 \\
\hline
\end{tabular}

Table 2d: Bad bank balance sheet prior to expiration (selling) date of toxic assets

\begin{tabular}{|lr|ll|}
\hline Assets & Liabilities & \\
\hline $\begin{array}{l}\text { Fundamental Value Toxic } \\
\text { Assets }\end{array}$ & 60 & Debt \\
\hline Annuity payment from bank & 30 & & \\
\hline Total Assets & 90 & Total Liabilities & 90 \\
\hline
\end{tabular}

Table 2e: Bad bank's final balance sheet

\begin{tabular}{|lr|ll|}
\hline Assets & Liabilities & 90 \\
\hline Selling price of Toxic Assets & 50 & Debt & \\
\hline Annuity payment from bank & 30 & & \\
\hline $\begin{array}{l}\text { Residual loss to be covered by } \\
\text { shareholders }\end{array}$ & 10 & & 90 \\
\hline Total Assets & 90 & Total Liabilities & \\
\hline
\end{tabular}

Total loss for shareholders $\quad \mathbf{5 0}$

The German government plan imposes a discount of 10 from the original book value of the toxic assets (Table $2 \mathrm{~b}$ ). The resulting write-offs cut the equity capital by the same amount. Let's assume that the independent accountants fix the fundamental value at the level of 60 . 
Therefore, in terms of present value, the bank transfers at the expense of its equity the additional discount of 30 to the bad bank over the next 20 years (Table $2 b$ and Table $2 d$ ).

The bad bank takes in the toxic assets for their fundamental value of 60 and hands over insured government bonds of value 90 in exchange (Table 2d). Assume that the bad bank uses zero bonds that expire after 20 years for this purpose. Those bonds can be used as collateral for an ECB loan that is needed to finance the additional discount of 30 . The bank's balance sheet contracts to a volume of 990 after the toxic assets are transferred and parts of the equity are swapped for debt (Table 2c).

With an equivalent selling price as in the above example, the final balance sheet of the bad bank (Table 2e) would show a residual deficit of 10, after paying off the expired zero bonds to the bank. With this amount the bank's shareholders would be still indebted to the taxpayers. 